Jurnal SEMAR Vol. 8 No. 1, 2019 hal. 1 - 8

ISSN: 2302-3937 | Copyright (C LPPM Universitas Sebelas Maret

Homepage: https://jurnal.uns.ac.id/jurnal-semar

\title{
MENINGKATKAN NILAI JUAL RAJUT DI MASYARAKAT \\ MELALUI DESAIN DAN MEDIA SOSIAL
}

\author{
Wisnu Wendanto ${ }^{1} \mid$ Yoiceta Vanda $^{1,{ }^{1}} \mid$ Muharini Syarifah $^{2}$ \\ ${ }^{1}$ Program Studi Teknik Elektronika, Akademi Teknologi AUB \\ ${ }^{2}$ Pondok Baru Gentan
}

\begin{abstract}
Abstrak
Kerajinan rajutan merupakan suatu produk rajutan hasil kerajinan tangan yang dilakukan secara manual. Tak sedikit produk fashion yang dibuat dari hasil rajutan, seperti baju, celana pendek, syal, sweeter, aksesoris, tas, dan produk yang lain. Berdasarkan permasalahan yang dihadapi oleh mitra, diperlukan suatu metode pendekatan yang sudah disepakati antara pihak Perguruan Tinggi dan pihak Mitra, yaitu : Pelatihan Internet, Pelatihan Merajut untuk ibu-ibu PKK, pelatihan Desain Grafis, Pembuatan Situs (World Wide Web). Kegiatan yang sudah dilaksanakan pada Program Kemitraan Masyarakat, adalah sebagai berikut : Pelatihan Merajut, Pelatihan Internet dan Pengelolaan Manajemen Website, pelatihan desain grafis.Setelah kegiatan ini dilaksanakan, ada beberapa kesimpulan yang dapat diambil, yaitu :Masyarakat sasaran yaitu ibu-ibu PKK, yang mempunyai usaha rumahan rajutan. masyarakat sasaran yaitu ibu-ibu PKK mendapatkan ketrampilan yang lebih baik untuk dapat menghasilkan produkproduk rajutan yang lebih inovatif, masyarakat sasaran mampu mengakses internet dan mengelola website sesuai dengan keinginan masing-masing. Setelah pembuatan Website, penjualan meningkat $10 \%$ dibandingkan dengan penjualan sebelum menggunakan website.
\end{abstract}

Kata Kunci: rajutan, website, pelatihan internet, pelatihan merajut

\section{Pendahuluan}

Dalam industri modern, pembuatan produk secara masal, merupakan suatu keniscayan. Melalui mesin industri yang makin canggih, suatu jenis produk dapat dibuat dalam jumlah banyak dengan bentuk yang sama, namun dalam waktu yang singkat. Inilah keuntungan industri. Namun bagi konsumen, produk masal bukan produk ekslusif, bahkan cenderung murah. Hal itu tentu berbeda dengan produk kerajinan rajutan yang merupakan hasil karya tangan yang unik dan bersifat ekslusif.

Membandingkan produk masal hasil industri dengan produk kreatif buatan tangan, terasa perbedaannya. Membeli suatu produk masal sebenarnya dihindari oleh konsumen, karena kurang memberikan nilai lebih. Kerajinan rajutan merupakan suatu produk rajutan hasil kerajinan tangan yang dilakukan secara manual. Tak sedikit produk fashion yang dibuat dari hasil rajutan, seperti baju, celana pendek, syal, sweeter, aksesoris, tas, sepatu, dan produk yang lain.

Dibandingkan produk masal buatan pabrik, hasil rajutan mempunyai nilai yang jauh lebih tinggi. Karena itu tak mengherankan jika harga jual produk rajutan relative mahal. Bukan hanya proses manual sehingga waktu penyelesaiannya yang relatif lama yang membuat produk rajutan menjadi mahal. Keistimewaan produk rajutan tangan terutama pada desain yang dibuat dan kerapian hasil produknya.

Pada Program pengabdian pada masyarakat Program Kemitraan Masyarakat (PKM) ini ada 2 mitra, yaitu :

\footnotetext{
*Penulis Korespondensi. Email: vandayoiceta@gmail.com
} 
Jurnal SEMAR Vol. 8 No. 1, 2019 hal. 1 - 8

1. Kelompok PKK Pondok Baru Gentan

Lokasi mitra 1 ini di Perumahan Pondok Baru Gentan, Gentan, Sukoharjo. Mulai membuat rajut pada tahun 2008. Produk pertama yang dibuat adalah bros untuk kerudung, tas, aksessoris wanita seperti jepit, bandana, sepatu bayi, tempat botol, dompet, syal, dan lain lain. Seiring berjalannya waktu, produk yang dibuat adalah khusus untuk produk sepatu rajut. Mulai dari sepatu rajut untuk bayi, untuk anak-anak, dan dewasa.

2. Kelompok PKK Pondok Baru 2 Gentan

Mitra yang kedua adalah Kelompok PKK Pondok Baru 2 Gentan yang berlokasi di Perumahan Pondok Baru II Gentan.
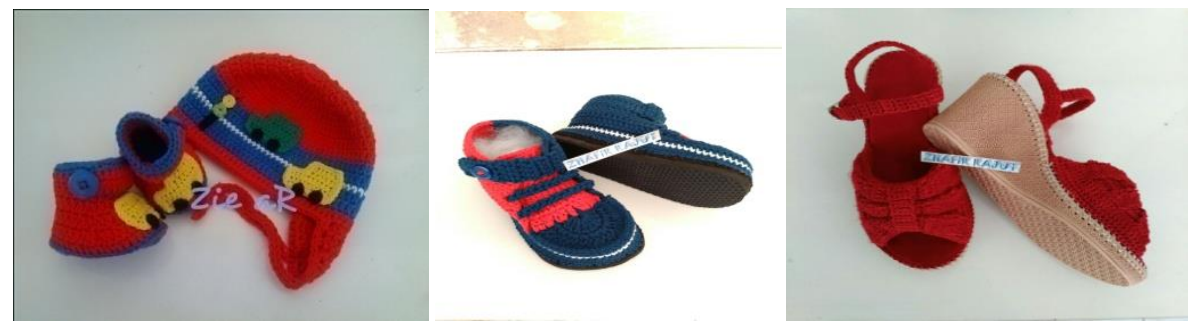

Gambar 1. Contoh produk sepatu yang dihasilkan

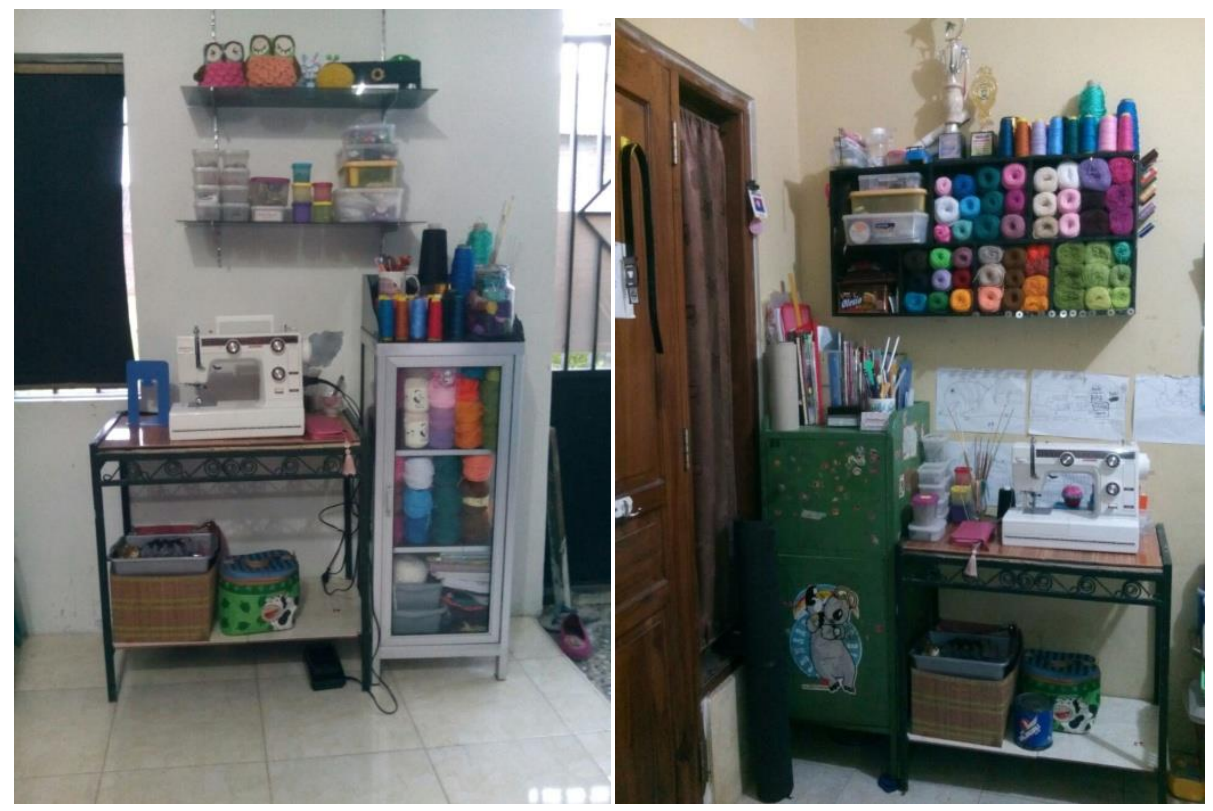

Gambar 2. Peralatan yang digunakan dalam membuat rajutan.

Mulai membuat rajutan tahun 2010. Produk pertama yang dibuat adalah bros untuk kerudung, tas, aksessoris wanita seperti jepit, bandana, sepatu bayi, tempat botol, dompet, syal, dan lain lain. Seiring berjalannya waktu, produk yang dibuat adalah khusus untuk produk baju, tas dan souvenir.

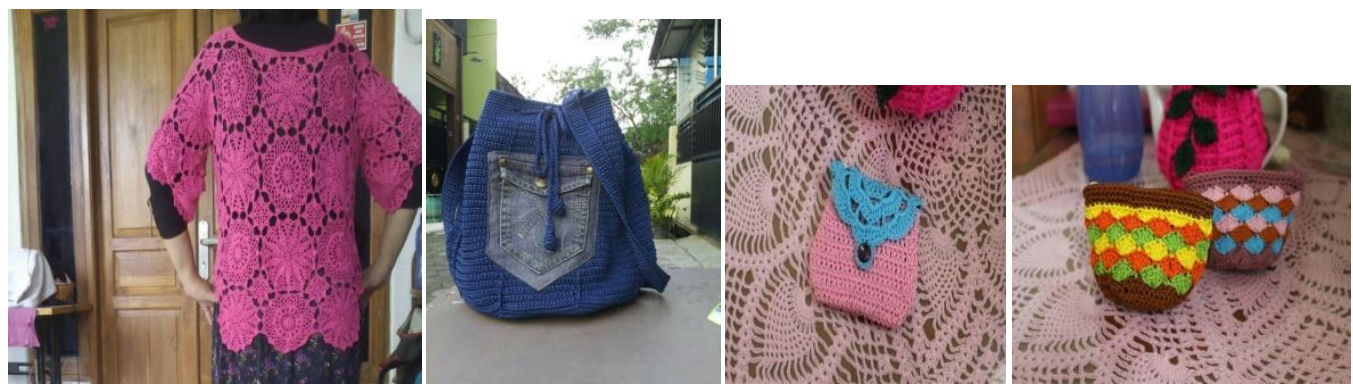

Gambar 3. Contoh produk yang dihasilkan 
Jurnal SEMAR Vol. 8 No. 1, 2019 hal. 1 - 8

\section{Aspek Produksi}

Ada beberapa langkah untuk merencanakan aspek produksi, yaitu :

1. Menetapkan skala produksi

Hasil kerajinan tangan rajutan ini merupakan produk yang eksklusif, dalam arti tidak diprosuksi secara masal. Sehingga produk yang dihasilkan adalah unik, tidak ada kesamaan pada tiap produk. Hasil kerajinan tangan rajut ini dibuat berdasarkan pada permintaan konsumen dengan model-model yang berbeda. Sehingga produk yang dihasilkan merupakan kreatifitas dari pembuatnya. Kualitas produk yang dihasilkan sangat diperhatikan, karena itulah proses pembuatan produk memerlukan waktu yang agak lama. Mulai dari pemilihan desain/model sampai ke produk jadi.

2. Pengolahan dan pengendalian persediaan bahan baku

Untuk bahan baku yang diperlukan dapat dengan mudah diperoleh di toko-toko terdekat. Apabila ada bahan baku lain yang tidak terdapat di Karanganyar, maka dapat diperoleh dengan memesan kepada agen/distributor dari luar kota. Terkadang pemesanan bahan baku di luar kota memerlukan waktu yang lama, sehingga pemesanan produk rajutan terhambat.

3. Proses produksi

Proses produksi hasil kerajinan tangan rajut adalah sebagai berikut :
a) Pemilihan desain/model
b) Pemilihan warna
c) Pemesanan oleh konsumen
d) Pembuatan produk
e) Hasilnya dikirimkan ke konsumen

4. Bahan baku yang dibutuhkan :

- Benang rajut, yaitu : Benang katun, katun rayon, katun lokal sembur, katun lokal polos, benang wol, benang rayon, dan benang jala.

- Manik-manik, fashion button.

- Karet rambut, jepit rambut.

- Peniti, dan lain-lain.

5. Penyimpanan hasil produksi

Untuk penyimpanan hasil produksi, dibuat sampel tiap model/desain, sehingga memudahkan konsumen untuk memilih sesuai dengan keinginan. Selain itu, untuk warnanya, ditampilkan juga macam-macam warna benang yang akan digunakan untuk rajutan. Hal tersebut juga dilakukan untuk keperluan pemasaran secara online melalui internet.

\section{Manajemen Usaha}

\section{Pemasaran}

Pemasaran yang dilakukan selama ini masih terbatas pada lingkungan sekitar. Untuk masyarakat diluar Surakarta, pemasaran dilakukan secara online. Tapi karena keterbatasan biaya permodalan dan sumber daya manusia, maka pemasaran secara online dilakukan melalui jejaring sosial yaitu facebook dan Whatsapp.

2. Pengelolaan sumber daya manusia

Untuk pengelolaan sumber daya manusia, dihadapkan pada kebutuhan sumberdaya manusia yang kurang memenuhi. Hal tersebut dikarenakan sumber daya yang bisa merajut masih sedikit jumlahnya. Untuk beberapa pesanan dengan jumlah banyak, memerlukan waktu yang cukup lama, dikarenakan keterbatasan sumber daya manusia. 
Jurnal SEMAR Vol. 8 No. 1, 2019 hal. 1 - 8

Berdasarkan analisis situasi yang telah dipaparkan diatas, diketahui permasalah yang dihadapi mitra adalah :

1. Penyediaan bahan baku

Untuk memperoleh bahan baku yang dibutuhkan dalam proses produksi ada yang mudah didapat, ada yang sulit didapat. Hal tersebut mempengaruhi dalam lamanya pembuatan produk rajutan.

2. Sumber daya manusia

Kurangnya sumber daya manusia yang bisa merancang (desain) produk menggunakan komputer, mengedit gambar produk yang akan dimasukkan ke katalog di dalam website yang sudah dimiliki.

3. Pemasaran/Marketing

Pemasaran yang dilakukan masih terbatas melalui internet yaitu melalui social network, seperti facebook dan whatsapp, serta website Diperlukan pemasaran yang lebih luas, menggunakan brosur maupun leaflet.

\section{Metode Pelaksanaan}

\section{Metode Pendekatan yang ditawarkan}

Berdasarkan permasalahan yang dihadapi oleh mitra, diperlukan suatu metode pendekatan yang sudah disepakati antara pihak Perguruan Tinggi dan pihak Mitra, yaitu:

1. Pelatihan Internet dan Pengelolaan Website

Untuk pengeloaan Bahan baku dengan cara memberikan pelatihan internet, agar dapat memesan bahan baku yang sulit didapat, melalui internet.

2. Pelatihan Desain Grafis

Pelatihan ini dimaksudkan untuk dapat memperoleh sumber daya manusia yang dapat merancang rajutan dengan baik.

3. Pelatihan Rajut

4. Pembuatan Situs (World Wide Web).

Situs ini digunakan untuk menampilkan model/desain rajutan yang dihasilkan, beserta cara pemesanannya.

5. Penambahan peralatan untuk membuat sepatu sesuai dengan standart nasional.

6. Pendaftaran merk dagang.

\section{Prosedur Kerja yang Mendukung Realisasi Metode yang Ditawarkan}

1. Mekanisme Hubungan Perguruan Tinggi penggusul dengan Mitra Pihak Mitra mempersiapkan sumber daya manusia yang akan mengikuti pelatihan Internet dan Pelatihan Merajut. Sedangkan pihak Perguruan Tinggi pengusul adalah mempersiapkan tempat dan materi pelatihan.

2. Standard operating Procedures (SOP)

Dipersiapkan oleh Perguruan Tinggi Pengusul dengan dibantu oleh salah satu sumber daya dari Mitra , berisi tentang langkah-langkah yang dilakukan untuk mengatasi permasalahan yang dihadapi mitra.

3. Evaluasi penerapan SOP. 
Jurnal SEMAR Vol. 8 No. 1, 2019 hal. 1 - 8

Dilakukan oleh Perguruan Tinggi Pengusul dan Mitra, setelah semua kegiatan dilaksanakan dengan baik dan benar. Hal ini diperlukan untuk melihat apakah ada peningkatan yang terjadi setelah dilakukan kegiatan.

\section{Langkah-langkah yang dilakukan}

Beberapa langkah yang dilakukan adalah :

1. Persiapan tempat bagi pelatihan internet, Desain grafis, dan pelatihan manajemen keuangan dan manajemen bisnis.

2. Persiapan materi pelatihan.

3. Penentuan waktu pelatihan

4. Pengumpulan data

5. Pembuatan Web/situs.

6. Pendaftaran merk dagang.

\section{Partisipasi Mitra Dalam Pelaksanaan Program}

Partisipasi mitra dalam pelaksanaan Program Kemitraan Masyarakat (PKM) ini adalah:

1. Pelatihan Internet

Mitra mempersiapkan sumber daya manusia yang akan mengikuti pelatihan.

2. Pelatihan Desain Grafis.

Mitra mempersiapkan sumber daya manusia yang akan mengikuti pelatihan.

3. Pelatihan Rajut

Mitra mempersiapkan sumber daya manusia yang akan mengikuti pelatihan.

4. Pembuatan Web/situs

Mitra memberikan data-data yang diperlukan dalam pembuatan Web, serta diminta untuk memberikan saran seperti apa web yang diiginkan oleh Mitra.

5. Pendaftaran merk dagang.

Mitra mempersiapkan semua berkas dan data yang diperlukan dalam proses pendaftaran merk dagang.

\section{Hasil dan Pembahasan}

Program Kemitraan Masyarakat (PKM) ini merupakan program kemitraan yang dilaksanakan di Kelurahan Gentan, Kabupaten Sukoharjo. Kegiatan ini dilakukan untuk meningkatkan nilai jual produk rajutan yang dihasilkan oleh ibu-ibu PKK Kelurahan Gentan, yang sebagian besar adalah ibuu rumah tangga. Ada beberapa kegiatan yang telah dilaksanakan, yaitu:

1. Pelatihan Desain Grafis

Pelatihan Desain Grafis ini dilakukan untuk mendukung ibu-ibu penghasil rajut, agar dapat menghasilkan gambar ataupun foto hasil rajutan yang sesuai sehingga bisa untuk promosi penjualan. Gambar hasil rajutan yang dihasilkan akan dibuat dalam katalog produk rajutan yang dibuat.

2. Pelatihan Rajut

Pelatihan ini dilaksanakan pada tanggal 24 Juni 2018, bertempat di Balekambang Surakarta, selama 1 hari. Peserta Pelatihan ada 12 orang terdiri dari perwakilan ibu-ibu PKK, dan perwakilan mahasiswa, serta perwakilan dosen. 
Jurnal SEMAR Vol. 8 No. 1, 2019 hal. 1 - 8

3. Pelatihan Pengelolaan Website

Pelatihan ini dilaksanakan pada tanggal 8 Juli 2018, bertempat di salah satu rumah ibu PKK di Kelurahan Gentan, Kabupaten Sukoharjo, selama 1 hari. Peserta Pelatihan ada 12 orang terdiri dari perwakilan ibu-ibu PKK, dan perwakilan mahasiswa, serta perwakilan dosen.

4. Pendaftaran Merk Dagang

Kegiatan ini dilakukan dengan tujuan untuk memberikan hak kepada pembuat rajut akan hasil rajutannya. Produk yang sudah mempunyai merk dagang akan lebih mudah dipasarkan pada pasar nasional maupun internasional.

5. Pembuatan Website

Pembuatan Website berisi tentang sejarah, gambar produk yang dihasilkan, cara memesan produk, sampai cara pembayaran. Dibuat website dengan alamat website yaitu http://www.zhafir-rajut.com. Menu-menu yang ditampilkan adalah profil, katalog produk, cara pembelian, kontak, sejarah. Tampilan website seperti terlampir.

Tabel 1. Spesifikasi pemasaran via internet

\begin{tabular}{|c|c|c|c|c|}
\hline No. & Profil/tampilan & Keterangan & Indikator & $\begin{array}{l}\text { Realisasi } \\
\text { Program }\end{array}$ \\
\hline 1. & Profil user & zhafir-rajutsolo.com & Mudah diingat & \multirow{3}{*}{$100 \%$} \\
\hline 2. & Operator & Admin & & \\
\hline 3. & Produk & Hasil Rajutan tangan & $\begin{array}{l}\text { Pemasaran } \\
\text { lebih efektif } \\
\text { dan praktis }\end{array}$ & \\
\hline
\end{tabular}

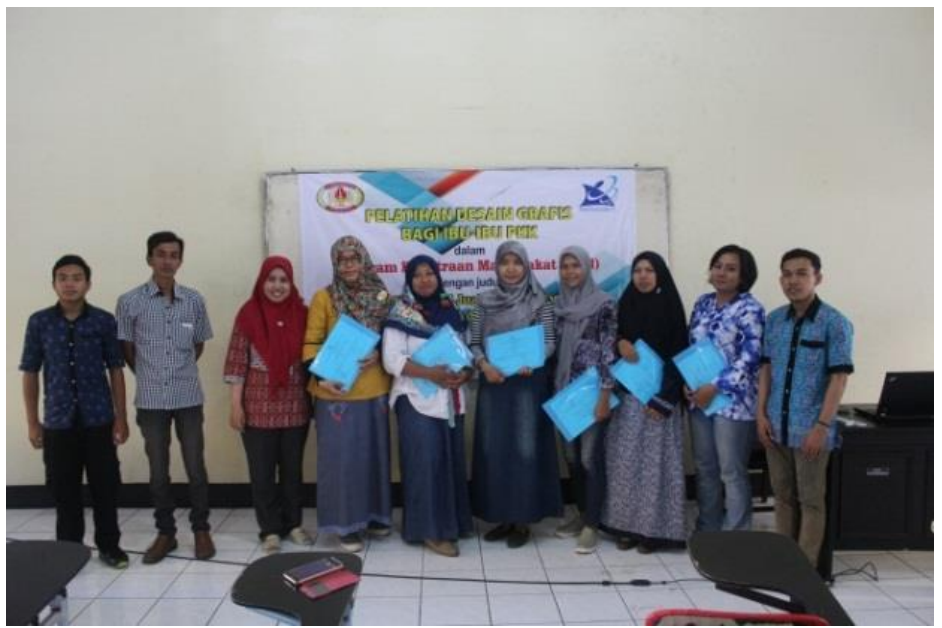

Gambar 4. Foto Kegiatan 
Jurnal SEMAR Vol. 8 No. 1, 2019 hal. 1 - 8

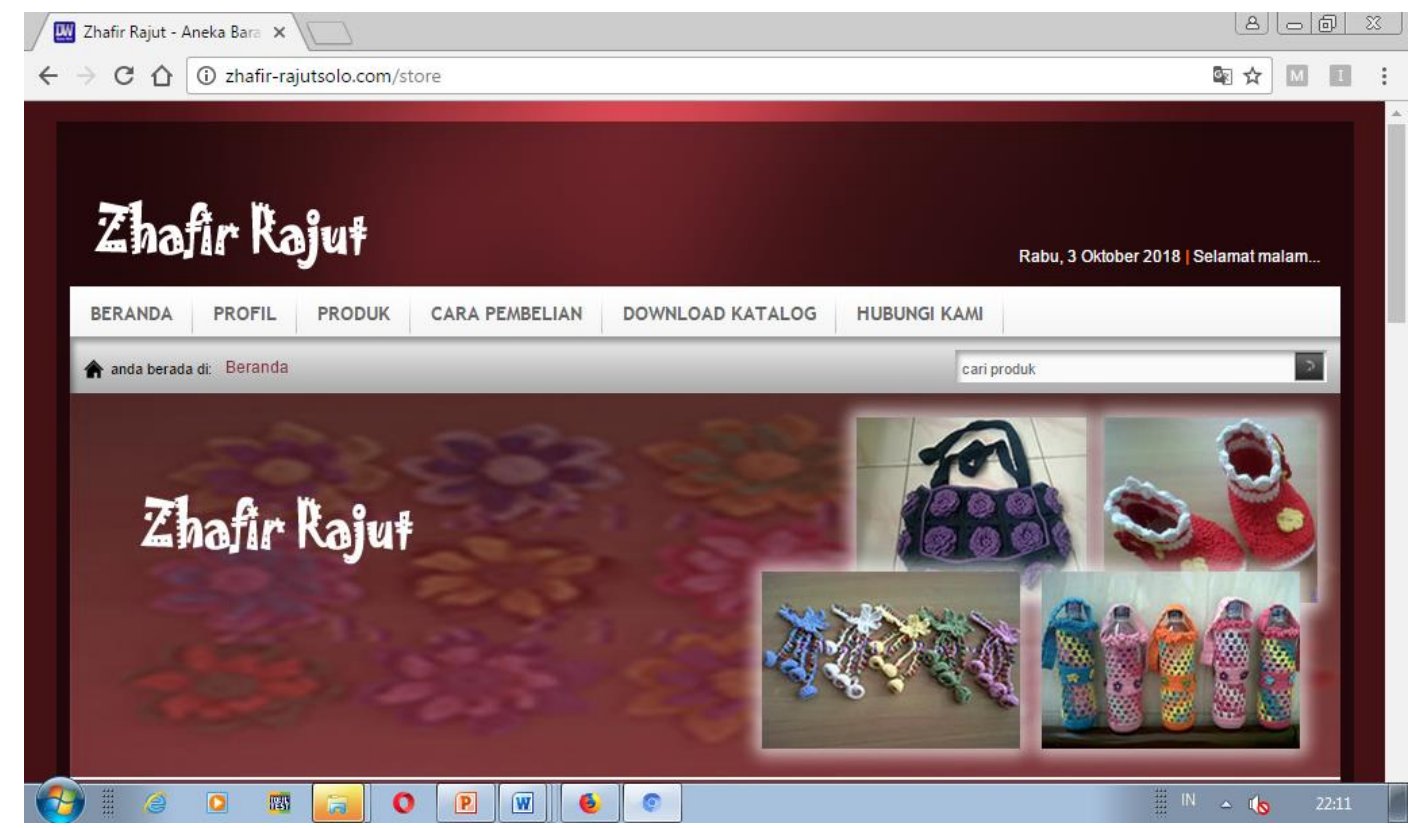

Gambar 5. Website rajut.

Dalam pelaksanaan semua kegiatan pada Program Kemitraan Masyarakat (PKM), ada beberapa kendala yang dihadapi oleh Tim Pelaksana di lapangan, adalah sebagai berikut :

1. Menentukan waktu yang tepat untuk mengumpulkan ibu-ibu PKK melaksanakan pelatihan.

2. Ada beberapa ibu-ibu yang belum mengetahui penggunaan komputer maupun laptop.

3. Banyak diantara ibu-ibu PKK yang mempunyai anak balita yang sulit untuk ditinggalkan.

4. Peralatan untuk membuat rajutan yang masih minim.

\section{Kesimpulan}

Program Kemitraan Masyarakat (PKM) ini merupakan program pengabdian Masyarakat dengan masyarakat sasaran Ibu Ibu PKK. Setelah kegiatan ini dilaksanakan, ada beberapa kesimpulan yang dapat diambil, yaitu :

1. Masyarakat sasaran yaitu ibu-ibu PKK, yang mempunyai usaha rumahan rajutan.

2. Setelah pelaksanaan kegiatan Pelatihan Merajut, masyarakat sasaran yaitu ibu-ibu PKK mendapatkan ketrampilan yang lebih baik untuk dapat menghasilkan produk-produk rajutanyang lebih inovatif.

3. Setelah pelaksanaan Pelatihan Internet dan Manajemen Pengelolaan Website, masyarakat sasaran mampu mengakses internet dan mengelola website sesuai dengan keinginan masing-masing.

4. Setelah pembuatan Website, penjualan meningkat $10 \%$ dibandingkan dengan penjualan sebelum menggunakan website.

5. Setelah Pelatihan Desain Grafis, diharapkan ibu-ibu PKK mampu membuat desain produk yang lebih bervariasi dan inovatif.

Pelaksanaan pengabdian PKM ini masih dalam tahap perbaikan sistem pemasaran dan peningkatan sumber daya manusia. Diharapkan dengan pelaksanaan kegiatan ini, masyarakat sasaran dapat mengembangkan potensi merajut dan dapat mengelola website dengan baik. Untuk pelaksanaan selanjutnya ibu-ibu PKK diharapkan mempunyai sebuah wadah yang dapat 
Jurnal SEMAR Vol. 8 No. 1, 2019 hal. 1 - 8

ISSN: 2302-3937 | Copyright @ LPPM Universitas Sebelas Maret

Homepage: https://jurnal.uns.ac.id/jurnal-semar

menampung para rajuter untuk dapat memasarkan produknya sampai ke luar negeri. Untuk desainnya, diharapkan mampu memberikan yang terbaru bagi para konsumen.

\section{Referensi}

Alma, Buchori, 2005. Manajemen Pemasaran dan Pemasaran Jasa. Bandung: Alfabeta.

Kotler, Philip dan Keller, Kevin Lane. 2009. Manajemen Pemasaran. Jakarta : Erlangga

“Cara Merajut dengan metode kniitting” http://id.wikipedia.org/wiki/Jarum_rajut,

http://admin panel.kidgoCMS. Kidgo CMS, “Admin Panel Kidgo CMS”, 2015 